\title{
Investigation of High School Students' Internet Addiction inThe Light of Various Variables
}

\section{Lise Öğrencilerinin İnternet Bağımlılıklarının Çeşitli Değişkenler Açısından İncelenmesi}

\author{
Deniz Mertkan GEZGIN**, Göknur KAPLAN AKILLI**
}

\begin{abstract}
The aim of this study was to investigate high school students' level of internet addiction and to determine internet addiction level according to various variables. The study was designed utilizing a survey model. The participants of the study were 501 high school students randomly selected from different socioeconomical districts, i.e., Selcuk district in Izmir and Central district in Edirne within the 2015-2016 academic year. Data were obtained through Internet Addiction Scale. Descriptive statistics utilizing MannWhitney and Kruskal-Wallis $\mathrm{H}$ tests were used for data analysis. The findings revealed low levels of Internet addiction for high school students along with the potential risk of Internet addiction. Furthermore, the differences between internet addiction level and grade level, mother's education level, smart phone ownership and mobile internet access were found to be statistically significant.
\end{abstract}

Keywords: Internet addiction, problematic internet use, mobile internet, adolescents

Öz: Çalışmanın amacı lise öğrencilerinin internet bağımlılı̆̆ı düzeylerini belinmesi ve çeşitli değişkenlere göre incelenmesidir. Tarama yöntemi yöntemi ile desenlenen çalışmanın katılımcı grubunu 2015-2016 eğitim-öğretim döneminde İzmir'in Selçuk ilçesi ve Edirne Merkez ilçesinde farklı sosyo-ekonomik yapılarda bulunan 501 lise öğrencisi oluşturmaktadır. Veriler “İnternet Bağımlılığı Ölçeği” ile toplanmıştır. Verilerin analizinde betimsel istatistikler ve non-parametrik testlerden Mann-Whithey ve Kruskal-Wallis testlerinden yararlanılmıştır. Çalışmanın bulgularına göre lise öğrencilerinin internet bağımlılığı düzeylerinin düşük olduğu,ancak potansiyel internet bağımlılığı riski taşıyan bireylerin olduğu tespit edilmiştir. Ayrıca, lise öğrencilerinin sınıf düzeyi, anne eğitim durumu, akıllı telefon sahipliliği ve mobil internet erişimi değişkenlerine göre anlamlı fark bulunmuştur.

Anahtar Kelimeler: İnternet bağımlılı̆̆ı, problemli internet kullanımı, mobil internet, ergenler

\section{Introduction}

As one of the greatest breakthroughs, internet provides us with access to institutions and resources about everything we want to know, explore, or operate. Considering these attributes, the added value of the internet to our lives is endless. On the other hand, recent studies put forth the negative effects of internet on individuals, more specifically, on children and adolescents. Many individuals are able to use internet in a controlled manner to complete a specific task, whereas there are several others who cannot control themselves in terms of internet use in their daily lives and experience various problems concerning work, family, school and social life due to excessive use of the internet. Numerous studies argue that such problematic and excessive use of Internet is an important factor in the deterioration of work and family relationships as well as one's own emotional balance and well-being (Anderson, 2001; Davis, 2001; Kim et al, 2006; Lin \& Tsai, 2002; Slavtcheva-Petkova, Nash \& Bulger, 2015; Young \&Rogers, 1998). Caplan (2002) identifies this kind of behavior as "pathological" or "problematic," since it shows a significant deviation from what is deemed to be normal, while creating problems for individuals and even

\footnotetext{
*Assistant Prof. Dr., Trakya University, Faculty of Education, Edirne-Turkey, e-mail: mertkan@ trakya.edu.tr

${ }^{* *}$ Lect. Dr., Middle East Technical University, Faculty of Education, Ankara-Turkey, e-mail: akilli@ metu.edu.tr
} 
damaging them. A brief literature review reveals that various researchers use various terminologies, such as "internet addiction" (Young, 1998; Ko et al, 2005) "pathological internet use" (Davis, 2001; Morahan-Martin \& Schumacher, 2000; Young, 1998), "problematic internet use" (Davis, Flett \& Besser, 2002; Shapira et al, 2003) to refer to such excessive use of internet without a specific purpose or direction. In a similar manner, there seems to be hardly any precise definition for the designated phenomenon. Young (1998) defines internet addiction as an impulse control disorder that does not contain any intoxicating substances. Moreover, Morahan-Martin and Schumacher (2000) define it as the serious damage to one's life due to that person's intense and uncontrollable internet use; whereas Beard and Wolf (2001) define it as the excessive use of internet that creates difficulties in people's family, work/school, social and psychological lives. However, the most widely-used term appears to be internet addiction (Byun, et al., 2009).

Excessive use of the Internet has a negative impact on the lives of adolescents as well as adults, since it may have harmful effects on adolescents' psychosocial development and behavior (Cam \& Nur, 2015). There are many studies that bring forward the correlation between internet addiction and psychiatric disorders such as depression, anxiety, sleep disorders, attention deficits, and hyperactivity disorder (Akin \& Iskender, 2011; Dalbudak et al, 2013; Sung et al, 2013).Literature review reveals that there are several studies conducted in Turkey investigating high school students' internet addiction: Investigating whether problematic internet use creates possible psychopathological symptoms and obesity cases in adolescents; Cam and Nur (2015) assert the prevalence of problematic internet use among adolescents as 7.1\%. Esen and Siyez (2011) scrutinize the relationship between internet addiction and academic achievement of high school students. Their findings reveal that students' mean scores received from internet addiction scale seem to differ according to academic achievement. Further analysis shows that internet addiction levels of students within the academic achievement range of "under 1.99" and " 2.00 to 2.99" are higher than students within the academic achievement range of " 4.50 to 5.00." These results suggest that excessive and problematic internet use might have a negative impact on students' academic achievement.

One of the reasons for excessive internet use might be the increasing ease to internet access through the agency of rapid technological developments, particularly of mobile technology, and widespread use of smart phones which replaced cell phones over time. As for the pervasive use of smart phones, some of the reasons might be listed as: the expansion of mobile internet, wireless internet accessibility, the enhancements in smart phone capacity (in terms of speed, capacity, operating system, etc.), and dropped prices. In a recent report published by Turkish Statistical Institute [TurkStat] (2015), the proportion of individuals using the Internet is given as 55.9\%. The percentage of households in Turkey with internet access by April 2015 is given as 69.5\%. It is also reported that $74.4 \%$ of the individuals used a mobile phone or a smart phone, whereas $28.9 \%$ used a portable computer (notebook, netbook, tablet, etc.) to access wireless Internet outside their homes and work within the first three months in 2015. As for the daily utilization rates, Internet users in Turkey spend an average of 4 hours 37 minutes on the internet, 2 hours 51 minutes on mobile internet and 2 hours 56 minutes on social media per day (We Are Social, 2015). Both reports reveal the increasing rates of mobile internet use and imply a possible increase in the internet addiction due to excessive use of internet via widespread adoption of smart phones and mobile internet access. Similarly, smart phones seem to overtake the computer use, not only by providing communication over wireless internet or mobile internet utilizing $4.5 \mathrm{G}$ technologies, but also offering special packages for online games, social network and chat that might imbue such addiction. Thus, mobile phone users, especially smart phone holders have the opportunity to use internet 24 hours a day via mobile internet access. Even though most of the studies in the literature investigating internet addiction address internet addiction based on the use of desktop and laptop computers, mobile internet addiction bears similar characteristics with the generic internet addiction concept (Kwon et al., 2013). Thus, propelled with the prevalence of smart phone ownership and mobile internet access, the risk of possible pervasiveness and increase in Internet addiction is becoming an important concern. 
Literature offers evidence that academic achievement and course motivation of secondary education students are negatively affected by their increased levels of internet addiction (Esen \& Siyez, 2011). Therefore, the current study aims to determine high school students' levels of internet addiction and to examine whether these levels change according to various variables such as mobile/smart phone ownership, mobile internet access, etc. Investigation and illustration of internet addiction is important, to prevent; to take the necessary measures against; to protect young people from; and to raise awareness of both educators and parents about such problems, which is anticipated to increase with the advancements in mobile technologies. In this context the following questions have been pursued:

1. What is the status of high school students' internet addiction?

2. How do the levels of internet addiction among high school students differs in relation to
a. gender?
b. school type?
c. students grade levels?
d. level of parents' education?
e. family income?
f. smart phone ownership and the duration of smart phone ownership?
g. mobile internet access and the duration of mobile internet access?

\section{Method}

The current study is designed as a survey research. Survey designs are descriptive models that attempt to illustrate a past or present situation as it is. Events, individuals or objects that are subject to research are described plainly within their own context and conditions. Researchers do not attempt to change or affect them in any way. The important thing is to explain and illustrate the situation under investigation in an appropriate manner (Karasar, 2005). The current study investigates high school students' reasons for using mobile internet and examines their levels of internet addiction with regards to a variety of variables.

\section{Participants}

The sample of the study consists of easily accessible 516 students, who were randomly selected from high schools in the central district of Edirne and Selcuk district of Izmir with differing socioeconomic status. In the process of data analysis, data from 15 of the 516 students were omitted, since their forms were not properly filled out. Thus, the participants of the study consist of 501 high school students. Their socio-demographic characteristics are presented in Table 1.

\section{Data Collection Instrument}

In the current study, the subscale of internet addiction from the "Adolescent Computer Addiction Scale" developed by Ayas, Cakir and Horzum (2011) wasused to determine the level of internet addiction. The internet addiction subscale has a total of 28 items, which has 5-point Likert type responses, ranging as 1 = "Rarely", 2 = "Sometimes", 3 = "Often", 4 = "Usually", 5 = "Always." All items had primary loading values ranged from .512 to .795 . Twenty-eight items explain the $29.49 \%$ of the total variance. Internal consistency of the scale was examined using Cronbach's alpha. Internal consistency test results for Internet addiction subscale were reported as .96 . However, for the current study Cronbach's alpha for internal consistency of the scale was calculated as .94. The maximum and the minimum scores that can be obtained from the scale was 28 and 140, respectively. The level of internet addiction increases as the scores obtained from the scale increases. The participants who scored between 140 and 112 were classified as "internet addicts," whereas the participants who scored between 111 and 70 were referred to as "at risk" and the rest are referred to as "not addicted" (Taylan \& Isik, 2015).

Table 1. Socio-demographic characteristics of the participants

$\begin{array}{ll}\text { Demographics } & \mathrm{N}\end{array}$




\begin{tabular}{|c|c|c|c|}
\hline \multirow{2}{*}{ City } & Izmir & 179 & 35.7 \\
\hline & Edirne & 322 & 64.3 \\
\hline \multirow{2}{*}{ Sex } & Male & 226 & 45.1 \\
\hline & Female & 275 & 54.9 \\
\hline \multirow{4}{*}{ School Type } & Anatolian High School & 273 & 54.5 \\
\hline & $\begin{array}{l}\text { Vocational and Technical High } \\
\text { School }\end{array}$ & 149 & 29.7 \\
\hline & Social Sciences High School & 60 & 12.0 \\
\hline & Religious Vocational High School & 19 & 3.8 \\
\hline \multirow[t]{4}{*}{ Grade } & 9th Grade & 275 & 54.9 \\
\hline & 10th Grade & 99 & 19.8 \\
\hline & 11th Grade & 80 & 16.0 \\
\hline & 12th Grade & 47 & 9.4 \\
\hline \multirow[t]{6}{*}{ Mother's Education Level } & No formal education & 24 & 4.8 \\
\hline & Elementary school & 194 & 38.7 \\
\hline & Middle School & 130 & 25.9 \\
\hline & High school & 125 & 25.0 \\
\hline & Bachelor's degree & 21 & 4.2 \\
\hline & Master's degree & 7 & 1.4 \\
\hline \multirow{6}{*}{ Father's Education Level } & No formal education & 4 & 0.8 \\
\hline & Elementary school & 138 & 27.5 \\
\hline & Middle School & 141 & 28.1 \\
\hline & High school & 159 & 31.7 \\
\hline & Bachelor's degree & 35 & 7.0 \\
\hline & Master's degree & 24 & 4.8 \\
\hline \multirow[t]{5}{*}{ Family Income } & Under $800 \mathrm{TL}$ & 29 & 5.8 \\
\hline & $800-1600 \mathrm{TL}$ & 183 & 36.5 \\
\hline & $1600-2400 \mathrm{TL}$ & 131 & 26.1 \\
\hline & $2400-3200 \mathrm{TL}$ & 98 & 19.6 \\
\hline & Over $3200 \mathrm{TL}$ & 60 & 12.0 \\
\hline \multirow[t]{2}{*}{ Smart Phone Ownership } & Yes & 476 & 95.0 \\
\hline & No & 25 & 5.0 \\
\hline \multirow{4}{*}{$\begin{array}{c}\text { Duration of Smart Phone } \\
\text { Ownership }\end{array}$} & No & 25 & 5.0 \\
\hline & Less than 1 year & 116 & 23.1 \\
\hline & $1-4$ years & 283 & 56.5 \\
\hline & 4 years & 77 & 15.4 \\
\hline \multirow[t]{2}{*}{ Mobile Internet Access } & Yes & 468 & 93.4 \\
\hline & No & 33 & 6.6 \\
\hline \multirow{4}{*}{$\begin{array}{c}\text { Duration of Mobile Internet } \\
\text { Access }\end{array}$} & No & 33 & 6.6 \\
\hline & Less than 1 year & 129 & 25.7 \\
\hline & $1-4$ years & 263 & 52.5 \\
\hline & 4 years & 76 & 15.2 \\
\hline Total & & 501 & 100 \\
\hline
\end{tabular}

\section{Data Collection and Analysis}

Researchers collected the data within the teaching hours in schools. Students were informed about the research in general and the data collection instrument, followed by information on voluntary participation in research. Afterwards, the students filled in the questionnaire that took approximately 10-15 minutes. Before starting the analysis, data were tested for normal distribution. This is basically the examination of the central distribution of the total points from 
the scale; skewness and kurtosis values along with the Kolmogorov-Smirnov test result that was observed to occur $\mathrm{p}<0.05$. In the light of these examinations, the data were concluded not to be a good fit with the normal distribution. Thus, researchers decided to use nonparametric statistics, i.e. Mann-Whitney U and Kruskal-Wallis $\mathrm{H}$ tests, to report descriptive statistics from the data set.

\section{Findings}

The research findings revealed the effects of gender, grade level, parents' education levels, family's economic status, smartphone ownership, duration of smart phone ownership, mobile internet access, and duration of mobile internet access on high school students' internet addiction status, respectively.

Table 2. High school students' Internet Addiction Status

\begin{tabular}{|c|c|c|}
\hline Internet Addiction Status & $\mathrm{N}$ & $\%$ \\
\hline Not Addicted & 354 & 70.7 \\
\hline At risk & 132 & 26.3 \\
\hline Addicted & 15 & 3.0 \\
\hline Total & 501 & 100.0 \\
\hline
\end{tabular}

To determine whether high school students' internet addiction levels changes with gender, Mann-Whitney U test was used. The Mann-Whitney U test revealed no significant gender difference in internet addiction levels $(U=30870.500, p=.899)$.

Table 3. Mann-Whitney U Test Results According to Gender

\begin{tabular}{lccccc} 
Group & $\mathrm{N}$ & Mean Rank & Sum of Ranks & $\mathrm{U}$ & $\mathrm{p}<$ \\
\hline Male & 226 & 250.10 & 56521.50 & 30870.500 & .899 \\
Female & 275 & 251.74 & 69229.50 & & \\
\hline
\end{tabular}

Since the distribution of scores received from internet addiction scale shows extreme deviation from the normal distribution, a non-parametric test, i.e. Kruskal-Wallis $\mathrm{H}$ test was used to examine significant changes in the means of internet addiction score according to grade level. The findings revealed significant differences in the mean scores of Internet Addiction Scale according to grade level $\left(\chi^{2}(3)=8.824, p<.05\right)$. To further investigate the differences between the grades, Mann-Whitney U test was utilized and the findings revealed that there were significant differences between 9th grade and 10th grade (in favor of 9th grade), 10th grade and 11th grade (in favor of 11th grade) and the 12th grade and 10th grade (in favor of 12th grade).

Table 4.Kruskal-Wallis H Test Results According to Grade Levels

\begin{tabular}{lcccc}
\hline Grade Level & N & Mean Rank & Sd & Chi-Square \\
\hline 9th Grade & 275 & 252.43 & 3 & $8.824^{*}$ \\
10th Grade & 99 & 217.34 & & \\
11th grade & 80 & 269.73 & & \\
12th Grade & 47 & 281.63 & & \\
\hline$* p<.05$ & & & &
\end{tabular}

Since the distribution of scores received from internet addiction scale shows extreme deviation from the normal distribution, Kruskal-Wallis $\mathrm{H}$ test was used to examine significant changes in the means of internet addiction score according to mother's education levels. The findings revealed significant differences in the mean scores of Internet Addiction Scale according to mother's education levels $(\chi 2(5)=16.233 ; p<.05)$. To further explore the differences, MannWhitney $U$ test was utilized and the findings revealed that there were significant differences between the groups, whose mothers had no formal education and whose mothers were elementary, 
middle, high school graduates as well as holders of bachelor's and master's degree (in favor of elementary, middle, high school graduates, bachelor's and master's degree).

Table 5. Kruskal-Wallis H Test Results According to Mother's Education Levels

\begin{tabular}{lcccc}
\hline Mother's Education Level & N & Mean Rank & Sd & Chi-Square \\
\hline No formal education & 24 & 155.29 & 5 & $16.233^{*}$ \\
Elementary school & 194 & 241.28 & & \\
Middle School & 130 & 261.61 & & \\
High school & 125 & 271.26 & & \\
Bachelor's degree & 21 & 280.64 & & \\
Master's degree & 7 & 200.93 & & \\
\hline
\end{tabular}
$* p<.05$

Since the distribution of scores received from internet addiction scale shows extreme deviation from the normal distribution, Kruskal-Wallis $\mathrm{H}$ test was used to examine significant changes in the means of internet addiction score according to father's education levels. There was no significant difference in the mean scores of Internet Addiction Scale according to father's education levels $(\chi 2(5)=1.508, p>.05)$.

Table 6. Kruskal-Wallis H Test Results According to Father's Education Levels

\begin{tabular}{lcccc}
\hline Father's Education Level & $\mathrm{N}$ & Mean Rank & $\mathrm{Sd}$ & Chi-Square \\
\hline No formal education & 4 & 199.13 & 5 & 1.508 \\
Elementary school & 138 & 249.26 & & \\
Middle School & 141 & 251.77 & & \\
High school & 159 & 249.32 & & \\
Bachelor's degree & 35 & 273.87 & & \\
Master's degree & 24 & 242.90 & & \\
\hline
\end{tabular}

Since the distribution of scores received from internet addiction scale shows extreme deviation from the normal distribution, Kruskal-Wallis $\mathrm{H}$ test was used to examine significant changes in the means of internet addiction score according to family's economic status. Findings revealed that there was no significant difference in the mean scores $\left(\chi^{2}(4)=2.493, p>.05\right)$.

Table 7. Kruskal-Wallis H Test Results According to Family's Economic Status

\begin{tabular}{lcccc}
\hline Family's Economic Status & N & Mean Rank & Sd & Chi-Square \\
\hline Under 800 TL & 29 & 219.21 & 4 & 2.493 \\
$800-1600$ TL & 183 & 258.55 & & \\
$1600-2400$ TL & 131 & 245.09 & & \\
2400-3200 TL & 98 & 247.68 & & \\
Over 3200 TL & 60 & 261.68 & & \\
\hline
\end{tabular}

Mann-Whitney U test was used to compare the changes in high school students' internet addiction levels according to smart phone ownership. The findings revealed a significant difference in favour of students who owned a smart phone $(U=3378.500, p=.000)$.

Table 8. Mann-Whitney U Test Results According to Smart Phone Ownership

\begin{tabular}{lccccc}
\hline Group & $\mathrm{N}$ & Mean Rank & Sum of Ranks & U & $\mathrm{p}<$ \\
\hline Yes & 476 & 256.40 & 122047.50 & 3378.500 & .000 \\
No & 25 & 148.14 & 3703.50 & & \\
\hline
\end{tabular}

Since the distribution of scores received from internet addiction scale shows extreme deviation from the normal distribution, Kruskal-Wallis $\mathrm{H}$ test was used to examine significant changes in the means of internet addiction score according to duration of smart phone ownership. 
Findings revealed that there was no significant difference in the mean scores of Internet Addiction Scale $\left(\chi^{2}(2)=.701, p>.05\right)$.

Table 9.Kruskal-Wallis H Test Results According to Duration of Smart Phone Ownership

\begin{tabular}{lcccc}
\hline Duration of Smart Phone Ownership & $\mathrm{N}$ & Mean Rank & Sd & Chi-Square \\
\hline Less than 1 year & 116 & 231.89 & 2 & .701 \\
1-4 years & 283 & 238.40 & & \\
More than 4 years & 77 & 248.81 & & \\
\hline
\end{tabular}

Mann-Whitney U test was used to compare the changes in high school students' internet addiction levels according to mobile internet access. The findings revealed a significant difference in favour of students who had mobile internet access $(U=4635.500, p=.000)$.

Table 10. Mann-Whitney U Test Results According to Mobile Internet Access

\begin{tabular}{lccccc}
\hline Group & $\mathrm{N}$ & Mean Rank & Sum of Ranks & $\mathrm{U}$ & $\mathrm{p}<$ \\
\hline Yes & 468 & 257.60 & 120554.50 & 4635.500 & .000 \\
No & 33 & 157.47 & 5196.50 & & \\
\hline
\end{tabular}

Since the distribution of scores received from internet addiction scale shows extreme deviation from the normal distribution, Kruskal-Wallis $\mathrm{H}$ test was used to examine significant changes in the means of internet addiction score according to duration of mobile internet access. Findings revealed that there was no significant difference in the mean scores of Internet Addiction Scale $(\chi 2(2)=4.311, p>.05)$.

Table 11. Kruskal-Wallis H Test Results According to the Duration of Mobile Internet Access

\begin{tabular}{lcccc}
\hline Duration of Mobile Internet Use & N & Mean Rank & Sd & Chi-Square \\
\hline Less than 1 year & 129 & 214,00 & 2 & 4,311 \\
1-4 years & 263 & 240,46 & & \\
More than 4 years & 76 & 248,68 & & \\
\hline
\end{tabular}

\section{Discussion and Conclusion}

The current study investigates the internet addiction levels of high school students and examines internet addiction level according to various variables. The discussion of the findings from the study will be presented in accordance with the order in the findings section of the study.

Even though internet addiction scores of the adolescents participated in the study were low with respect to internet addiction levels, it was found that the addiction scores were influenced by many factors. Based on the score classification obtained from the scale, it was found that $3 \%$ of the adolescents were addicted to the internet, $26.3 \%$ were at risk, and $70.7 \%$ were not addicted. Although there are studies in the existing literature that suggest different addiction scores, there are also several studies reporting low levels of internet addiction scores (Hazar, Mamak \& Cinar, 2015), which are consistent with the current study, such as 2.33\% (Gokcearslan \& Gunbatar, 2012), 3.6\% (Simsek, Akca \& Simsek, 2015), 4.1\% (Taylan \& Isik, 2015), 7.1\% (Cam \& Nur, 2015). Moreover, in various other studies conducted in different cultures and regions by using different measurement tools; low and high addiction scores, as well as problematic internet use scores were obtained (Aktepe, Olgac-Dundar, Soyoz \& Sonmez, 2013; Kormas et al, 2011; Kubey, Lavin \& Barrows, 2001; Lam et al, 2009; Park, Kim \& Cho, 2008; Sinkkonen, Puhakka, Meriläinen, 2014; Tang et al, 2014). In consideration with a $6 \%$ estimate of overall internet addiction prevalence throughout the world, our finding that $3 \%$ of participants are addicted seems to be a serious issue that should be taken under consideration which might lead to possible problems in terms of problematic use of internet (Cheng \& Li, 2014).

In terms of internet addiction levels with respect to gender, no significant differences were found in the current study. This is consistent with the findings from several studies reporting 
no significance difference between males and females in terms of internet addiction (Balci \& Gulnar, 2009; Ceyhan, 2011; Scherer, 1997) as well as internet use (Cam \& Nur, 2015).

On the other hand, in existing literature there are quite many studies that suggest increased internet addiction rates among male students (Armstrong, Phillips \& Saling, 2000; Balta \& Horzum, 2008; Bayhan, 2011; Chou \& Hsiao, 2000; Esen \& Gundogdu, 2010; Esen \& Siyez, 2011; Ferraro et al, 2007; Gokcearslan \& Seferoglu,2016; Koch \& Pratarelli, 2004; Mythily, Qiu, \& Winslow, 2008; Oktan, 2015; Ozcan \& Buzlu, 2007; Simkova \& Cincera, 2004; Y1lmaz, Sahin, Haseski \& Erol, 2014, Wu \& Tsai, 2006; Zorbaz \& Dost, 2014), while a few others conclude that female students tend to be more addicted to the internet (Brenner, 1997; Young, 1998).

On the basis of grade level, a significant variation was found in terms of internet addiction levels. In existing literature, the number of studies focusing on the relationship between internet addiction and grade level is scarce. Therefore, grade level was especially concentrated upon in this study. The findings, revealed that there were significant differences between $9^{\text {th }}$ grade and $10^{\text {th }}$ grade students (in favor of the $9^{\text {th }}$ grade), between $10^{\text {th }}$ grade and 11 th grade students (in favor of the 11th grade), and 10th grade and 12th grade students (in favor of the 12th grade). Ninth grade students make up approximately half of the sample group (54.6\%) in this study and their internet addiction rate is higher than the 10th grade students. Such difference might stem from lack of friendships and social interaction because of 9th graders recent enrolment in high school as newcomers compared to 10th graders, who have more sound relationships among their classmates or friends from extracurricular activities in the school. This finding is consistent with Gunuc's (2009) study, where she pointed out that the highest rate of internet addiction was found among the 9 th grade students.

Moreover, our findings further revealed that the internet addiction scores of the 11th and 12th grade students were higher than those of the 10th grade students. This is consistent with Ceyhan's (2011) study, which indicates that the first years of high school education is a significant risk factor in the development of problematic internet use. It may be maintained that the reasons for the increase of internet addiction in line with this grade level are wider experience in internet and technology use and resorting to the internet as an escape from the challenges and the stress that is commonly observed in the period leading up to the university placement exams. There are studies which suggest that the internet addiction levels of the adolescents are increased in these periods where they experience fewer teachers and parental support and more peer pressure (Esen \& Gundogdu, 2010; Lam et al., 2009; Whang, Lee, \& Chang, 2003; Wentzel, 1998). In addition to this, Esen and Siyez (2011) report a negative relationship between perceived social support from the parents and internet addiction in their study. It may be concluded from the findings that it is important to conduct further studies to find out the actions students take to fit in the school environment as newcomers. What is more, contrary to findings of the present study, there are also a few recent studies reporting that grade level does not have any influence on internet addiction (Ancel, Acikgoz \& Ayhan, 2015; Cakir, Ayas \& Horzum, 2011; Ergin, Uzun \& Bozkurt, 2013).

A significant difference in internet addiction levels was discovered with respect to the educational level of the mothers of the participants. The findings indicate significant differences between the children of mothers with no education and of those with elementary, secondary, and undergraduate level educational credentials. Accordingly, the internet addiction scores of the students whose mothers have elementary, secondary, and undergraduate level education are higher than those whose mothers have no education. This may be attributable to the fact that mothers with higher education levels are more likely to be a working mom who spends more time at work and spare less time to spend with their children (Gokcearslan \& Seferoglu, 2016). On the other hand, Lam et al (2009) and Gökçearslan and Gunbatar (2012) report no significant differences in the internet addiction levels with respect to the education level of the mothers of the participants. What is more, they further state that there was no significant difference in the internet addiction levels according to fathers' education level. Similarly, our finding revealed no significant differences in the internet addiction levels with respect to the education level of the fathers. 
The findings revealed no significant difference in the internet addiction levels with respect to the income levels of the households of the participants. There are studies in the existing literature that support this finding (Balta \& Horzum, 2008; Esen \& Siyez, 2011; Park, Kim \& Cho; 2008). On the other hand, Bayraktar's (2001) study opposes this finding, articulating that there is a positive relationship between the internet use of the adolescents and the socio-economic levels of their families.

With respect to smart phone ownership of the participants, the study revealed a significant difference in the internet addiction levels. It was found that the internet addiction of individuals who own smart phones was higher than those who do not own smart phones. From the demographics of the study sample, $95 \%$ of the adolescents were found to possess a smart phone, which was not surprising since as a recent study conducted with 13,500 students revealed the smart phone ownership rate in Turkey as $80 \%$ (Google, MEB \& IGK, 2015). The smart phone ownership may imply mobile internet access which grants use of mobile activities such as social networking, communication, music, and thus bring about problematic and excessive use of internet (Byun, et al., 2009). However, with respect to the duration of smart phone use of the participants, no significant difference in the internet addiction levels could be found, which was a peculiar and unprecedented result for the researchers. It might be explained by the low level of internet addiction based on the score obtained from the scale. After all, it is known that individuals with social concerns are more inclined to use smart phones (Lee et al., 2014), which arises as a factor that influences the internet addiction of adolescents.

A significant difference in the internet addiction levels was found with respect to mobile internet ownership of the participants. It was discovered that the internet addiction of individuals who own mobile internet was higher than those who do not own mobile internet. As was found in this study, $93.4 \%$ of the adolescents have mobile internet access. In support of this finding, in the Turkish Statistical Institute [TurkStat]'s research (2015) it was found that $74.4 \%$ of the individuals who used the internet in the first three months of 2015 used mobile or smart phones to access the internet outside of their homes and workplaces, while $28.9 \%$ used mobile computers (laptops, netbooks, tablets etc.). It might be concluded that there seems to be an increasing trend to access the internet through mobile devices. Surprisingly though, the study revealed no significant difference in the internet addiction levels with respect to the duration of mobile internet use of the participants. This particular finding was also unanticipated for the researchers since it is acknowledged that internet use frequency has a positive relationship with internet addiction (Akbulut \& Yilmazel, 2012; Cao et al, 2011; Demir, Ozkoklu \& Turgut, 2015). It is suggested that studying the daily duration of mobile internet use through smart phones, which is increasingly common among the youth, would be more meaningful to understand its impact along with further examination of the students' purposes for using mobile internet, which might shed light on the types of mobile applications that might lead to internet addiction.

To sum up, problematic internet use and internet addiction may create adverse effects on adolescents' growth, social lives, and academic achievement levels. Therefore, problematic internet use as well as internet addiction needs to be thoroughly examined along with their causes. Today, the duration, means, context, and variety of internet use among the adolescents is increasing, just like it does among the adults. Thus, parents have great responsibility in this respect. Firstly, it must be noted that there is a positive relationship between problematic internet use, problematic family relations and unhealthy family life (Lam et al., 2009, Caplan, 2003; Caplan, 2005). Parents should be educated about the problem-free and constructive uses of the internet; encouraged to monitor the internet use by adolescentsespecially through smart phonesand they should act as stakeholders in the realization of measures against internet addiction, given that the lack of control and restraint may play a triggering role in the emergence of addiction (Simsek, Akca \& Simsek, 2015; Gokcearslan \& Seferoglu, 2016). Furthermore, it is anticipated that the encouragement of adolescents into sports and arts activities in their leisure time may have positive effects on their development (Cam \& Nur, 2015). Additionally, it is important to implement educational activities at schools about informed internet use in order to increase awareness about internet addiction with the collaboration of all stakeholders (Esen \& 
Siyez, 2011; Gokcearslan \& Seferoglu, 2016). In view of the wide ownership of smart phones and mobile internet among the youth, the prohibition or restriction of smart phones during class hours or on school grounds might prevent addiction, while creating positive impact on the students' academic achievement by motivating them in the course subjects. However, informative educational activities and training along with the monitored use of internet is thought to be more effective than the prohibition or restriction on the internet use. Overall, the study findings suggest that students, families and other related institutions should take certain responsibilities and precautions regarding the prevention of internet addiction with the requirement of all stakeholders' collaboration.

\section{Limitations}

The present study only includes high school students with different socio-economic backgrounds in the Selcuk district of İzmir province, and the central province of Edirne. Thus, future studies should be repeated with more comprehensive and different sample groups. It is also observed that most of the internet addiction studies are quantitative in nature. Future studies may utilize qualitative research methods beside experimental ones to disclose other aspects of the problem. Lastly, future studies should investigate the daily mobile internet use frequency, as it would be important in terms of revealing the relationship between the spread of mobile technologies and internet addiction. Consultancy works may also be planned and implemented in order to prevent problematic internet use and computer addiction (Sargin, 2013).

\section{References}

Akbulut, A.B., \& Yilmazel, G. (2012). Ergen yaş grubunda internet bağımlıllı̆ı düzeyinin

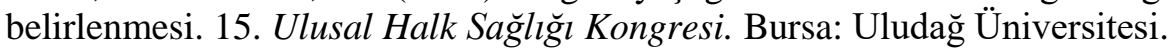

Akin, A., \& Iskender, M. (2011). Internet addiction and depression, anxiety and stress. International online journal of educational sciences, 3(1), 138-148.

Aktepe E, Olgac-Dundar, N, Soyoz, O., \& Sonmez, Y. (2013). Possible internet addiction in high school students in the city center of Isparta and associated factors: a cross-sectional study. The Turkish Journal of Pediatrics, 55(4), 417-425.

Ancel, G., Acikgoz, I.., \& Ayhan, A.G.Y. (2015). Problemli internet kullanımı ile duygusal zeka ve bazı sosyodemografik değişkenler arasındaki ilişki. Anatolian Journal of Psychiatry/Anadolu Psikiyatri Dergisi, 16(4), 255-263.

Anderson, K. J. (2001). Internet use among college students: An exploratory study. Journal of American College Health, 50(1), 21-26.

Armstrong, L., Phillips, J.G., \& Saling, L.L. (2000). Potential determinants of heavier Internet usage. International Journal of Human-Computer Studies, 53(4), 537-550.

Ayas, T., Cakir, O., \& Horzum, M. B. (2011). Adolescent's computer addiction scale. Kastamonu Education Journal, 19(2), 339-448.

Balci, Ş., \& Gulnar, B. (2009). Üniversite öğrencileri arasında internet bağımlılığ ve internet bağımlılarının profili.Selçuk Üniversitesi İletişim Fakültesi Akademik Dergisi, 6(1), 522.

Balta O.C. \& Horzum M.B. (2008). Web tabanlı öğretim ortamındaki öğrencilerin internet bağımlılığını etkileyen faktörler. Ankara Üniversitesi Ĕ̆itim Bilimleri Fakültesi Dergisi, 4l(1), 187-205.

Bayhan V. (2011). Lise öğrencilerinde internet kullanma alışkanlığ1 ve internet bağımlılığ1 (Malatya Uygulamas1). Akademik Biliş̧im'11-XIII. Akademik Biliş̧im Konferansı Bildirileri, Malatya: İnönü Üniversitesi 2-4 Şubat 2011, 917-924.

Bayraktar, F. (2001). İnternet kullanımının ergen gelişimindeki rolü. Yayımlanmamış yüksek lisans tezi, İzmir: Ege Üniversitesi, Sosyal Bilimler Enstitüsü.

Beard, K.W., \& Wolf, E.M. (2001). Modification in the proposed diagnostic criteria for Internet addiction. Cyber Psychology \& Behavior, 4(3), 377-383. 
Brenner, V. (1997). Psychology of computer use: XLVII. Parameters of Internet use, abuse and addiction: the first 90 days of the Internet Usage Survey. Psychological reports, 80(3), 879-882.

Byun, S., Ruffini, C., Mills, J.E., Douglas, A.C., et al. (2009). Internet addiction: metasynthesis of 1996-2006 quantitative research. Cyber Psychology \& Behavior, 12(2), 203-207.

Caplan, S.E. (2002). Problematic Internet use and psychosocial well-being: development of a theory-based cognitive-behavioral measurement instrument. Computers in Human Behavior, 18(5), 553-575.

Caplan, S.E. (2003). Preference for online social interaction a theory of problematic Internet use and psychosocial well-being. Communication Research, 30(6), 625-648.

Caplan, S.E. (2005). A social skill account of problematic Internet use. Journal of Communication, 55(4), 721-736.

Cao, H., Sun, Y., Wan,Y., Hao J., \& Tao F. (2011). Problematic Internet use in Chinese adolescents and its relation to psychosomatic symptoms and life satisfaction. Public Health, 11, 802-823.

Ceyhan, A. A. (2011). Ergenlerin problemli internet kullanım düzeylerinin yordayıcıları. Çocuk ve Gençlik Ruh Sağlı̆̆l Dergisi, 18(2), 85-94.

Cheng, C., \& Li, A. Y.L. (2014). Internet addiction prevalence and quality of (real) life: A metaanalysis of 31 nations across seven world regions. Cyberpsychology, Behavior \&Social Networking, 17(12), 755-760.

Chou, C., \& Hsiao, M.C. (2000). Internet addiction, usage, gratification, and pleasure experience: The Taiwan college students' case. Computers \& Education, 35(1), 65-80.

Cakir, O., Ayas, T., \& Horzum, M.B. (2011) Üniversite öğrencilerinin internet ve oyun bağımlılıklarının çeşitli değişkenlere göre incelenmesi. Ankara Üniversitesi Ĕğitim Bilimleri Fakültesi Dergisi; 44(2), 95-117.

Cam, H.H., \& Nur, N. (2015). Adölesanlarda internet bağımlılığı prevalansı ile psikopatolojik semptomlar ve obezite arasındaki ilişkinin incelenmesi. TAF Preventive Medicine Bulletin, 14(3), 181-188.

Dalbudak, E., Evren, C., Aldemir, S., Coskun, K.S., Ugurlu, H., \& Yildirim, F.G. (2013). Relationship of internet addiction severity with depression, anxiety, and alexithymia, temperament and character in university students. Cyberpsychology, Behavior \&Social Networking, 16(4), 272-278.

Davis, R.A. (2001). A cognitive-behavioral model of pathological Internet use. Computers in Human Behavior, 17(2), 187-195.

Davis, R.A., Flett, G.L., \& Besser, A. (2002). Validation of a new scale for measuring problematic Internet use: Implications for pre-employment screening. Cyber Psychology \& Behavior, 5(4), 331-345.

Demir, I., Ozkoklu, D.P., \& Turgut, B.A. (2015). Ergenlerin problemli internet kullanımının yordanmasında denetim odağ ve yaşam doyumunun rolü. Mersin Üniversitesi Ĕgitim Fakültesi Dergisi, 11(3), 720-731.

Ergin, A., Uzun, S.U. \& Bozkurt, A.I. (2013). Tıp Fakültesi öğrencilerinde internet bağımlılığ sıklığ 1 ve etkileyen etmenler. Pamukkale Tip Dergisi, 6(3), 134-142.

Esen, E., \& Siyez, D.M. (2011). Ergenlerde internet bağımlılı̆ıını yordayan psiko-sosyal değişkenlerin incelenmesi. Türk Psikolojik Danışma ve Rehberlik Dergisi, 4(36), 127138.

Esen, B.K., \& Gundogdu, M. (2010). The relationship between internet addiction, peer pressure and perceived social support among adolescents. The International Journal of Educational Researchers, 2(1), 29-36.

Ferraro G., Caci B., D’Amico A., \& Blasi M. (2007). Internet addiction disorder: An Italian study. Cyber Psychology \& Behavior, 10 (2), 170-175.

Google, MEB \& IGK (2015). Bilinçli internet kullanımı araştırması. 16 Aralık 2016 tarihinde http://www.kesfetprojesi.org/source/Bilincli_internet_Kullanim\%20Arastirmasi.pdf adresinden alınmıştır. 
Gokcearslan, S., \& Gunbatar, M.S. (2012). Ortaöğrenim öğrencilerinde internet bağımlılı̆̆ı. Eğitim Teknolojisi Kuram ve Uygulama, 2(2), 10-24.

Gokcearslan, S., \& Seferoglu, S.S. (2016). The use of the Internet among middle school students: Risky behaviors and opportunities. Kastamonu Education Journal, 24(1), 383-401.

Gunuc, S. (2009). Internet bağımlılık ölçeğinin geliştirilmesi ve bazı demografik değişkenler ile internet bağımlılığı arasındaki ilişskilerin incelenmesi. Yayımlanmamış yüksek lisans tezi. Van: Yüzüncü Y1l Üniversitesi Sosyal Bilimler Enstitüsü.

Hazar, K., Mamak, H., \& Cinar, V. (2015) Investigation of Relationship Internet and Computer Games Addiction with Sports Participation Level and Some Variables in High School Students. Beden Egitimi ve Spor Bilimleri Dergisi, 9(2), 259-268.

Karasar, N. (2005). Bilimsel araştırma yöntemi.Ankara: Nobel Yayin Dagitim.

Kim, K., Ryu, E., Chon, M.Y., Yeun, E.J., Choi, S.Y., Seo, J.S., \& Nam, B.W. (2006). Internet addiction in Korean adolescents and its relation to depression and suicidal ideation: a questionnaire survey. International Journal of Nursing Studies, 43(2), 185-192.

Ko, C.H., Yen, J.Y., Chen, C.C., Chen, S.H., \& Yen, C.F. (2005). Proposed diagnostic criteria of Internet addiction for adolescents. The Journal of Nervous \& Mental Disease, 193(11), 728-733.

Koch, W.H., \& Pratarelli, M.E. (2004). Effects of intro/extraversion and sex on social internet use. North American Journal of Psychology, 6(3), 371-382.

Kormas, G., Critselis, E., Janikian, M., Kafetzis, D., \& Tsitsika, A. (2011). Risk factors and psychosocial characteristics of potential problematic and problematic internet use among adolescents: a cross-sectional study. BMC Public Health, 11(1), 1.

Kubey, R.W., Lavin, M.J., \& Barrows, J.R. (2001). Internet use and collegiate academic performance decrements: Early findings. Journal of Communication, 51(2), 366-382.

Kwon, M., Lee, J.Y., Won, W.Y., Park, J.W., Min, J.A., Hahn, C., \& Kim, D. J. (2013). Development and validation of a smartphone addiction scale (SAS). PloS one, 8(2), e56936.

Lam, L.T., Peng, Z.W., Mai, J.C., \& Jing, J. (2009). Factors associated with internet addiction among adolescents. Cyber Psychology \& Behavior, 12(5), 551-555.

Lee, Y.K., Chang, C.T., Lin, Y., \& Cheng, Z.H. (2014). The dark side of smartphone usage: Psychological traits, compulsive behavior and technostress. Computers in Human Behavior, 31, 373-383.

Lin, S.S., \& Tsai, C.C. (2002). Sensation seeking and internet dependence of Taiwanese high school adolescents. Computers in Human Behavior, 18(4), 411-426.

Morahan-Martin, J., \& Schumacher, P. (2000). Incidence and correlates of pathological Internet use among college students. Computers in Human Behavior, 16(1), 13-29.

Mythily, S., Qiu, S., \&Winslow, M. (2008). Prevalence and correlates of excessive internet use among youth in Singapore. Annals Academy of Medicine, 37(1), 9-14.

Oktan, V. (2015). Üniversite öğrencilerinde problemli internet kullanımı, yalnızlık ve algılanan sosyal destek.Kastamonu Education Journal, 23(1), 281-292.

Ozcan, N.K., \& Buzlu, S. (2007). Internet use and its relation with the psychosocial situation for a sample of university students. Cyberpschology \& Behaviour, 10(6), 767-772.

Park, S.K., Kim, J.Y., \& Cho, C.B. (2008). Prevalence of internet addiction and correlations with family factors among South Korean adolescents. Adolescence, 43(172), 895-909.

Sargin, N. (2013). Üniversite öğrencilerinin internete yönelik tutumları ve problemli internet kullanımları. Turkish Journal of Education, 2(2), 44-53.

Shapira, N.A., Lessig, M.C., Goldsmith, T.D., Szabo, S.T., Lazoritz, M., Gold, M.S., \& Stein, D.J. (2003). Problematic internet use: proposed classification and diagnostic criteria. Depression \& Anxiety, 17(4), 207-216.

Sherer K. (1997). College life on-line: Healthy and unhealthy Internet use. Journal of College Student Development, 38(6), 655-665.

Simkova, B., \& Cincera, J. (2004). Internet addiction disorder and chatting in the Czech Republic. CyberPsychology \& Behavior, 7(5), 536-539. 
Simsek, N., Akca N.K. \& Simsek, M. (2015). Lise öğrencilerinde umutsuzluk ve internet bağımlılı̆̆ı.TAF Preventive Medicine Bulletin, 14(1), 7-14.

Sinkkonen, H.M., Puhakka, H. \& Meriläinen, M. (2014) Internet use and addiction among Finnish Adolescents (15-19 years). Journal of Adolescence. 37(2): 123-131.

Slavtcheva-Petkova, V., Nash, V.J., \& Bulger, M. (2015). Evidence on the extent of harms experienced by children as a result of online risks: implications for policy and research. Information, Communication \& Society, 18(1), 48-62.

Sung, J., Lee, J., Noh, H.M., Park, Y.S., \& Ahn, E.J. (2013). Associations between the risk of internet addiction and problem behaviors among Korean adolescents. Korean Journal of Family Medicine, 34(2), 115-122.

Tang, J., Yu, Y., Du, Y., Ma, Y., Zhang, D. \& Wang, J. (2014) Prevalence of internet addiction and its association with stressful life events and psychological symptoms among adolescent internet users. Addictive Behaviors, 39(3), 744-747.

Taylan, H.H., \& Isik, M. (2015). Sakarya' da ortaokul ve lise öğrencilerinde internet bağımlılı̆̆ı. Turkish Studies-International Periodical for the Languages, Literature and History of Turkish or Turkic, 10(6), 855-874.

TUIK [TurkStat]. (2015). Hanehalkı bilişim teknolojileri kullanım araştırması. 26 Mart 2016 tarihinde http://www.tuik.gov.tr/PreHaberBultenleri.do?id=18660adresinden alınmıştır.

Yilmaz, E., Sahin, Y.L., Haseski, H.İ., \& Erol, O. (2014). Lise öğrencilerinin internet bağımlılık düzeylerinin çeşitli değişkenlere göre incelenmesi: Balıkesir ili örneği. Journal of Educational Sciences Research, 4(1), 133-144.

Young, K. (1998). Internet addiction: The emergence of a new clinical disorder. CyberPsychology \&Behavior, 1(3), 237-244.

Young, K.S., \& Rogers, R.C. (1998). The relationship between depression and Internet addiction. CyberPsychology \& Behavior, 1(1), 25-28.

We Are Social (2015). Digital, social \& mobile worldwide in 2015. 26 Temmuz 2016 tarihinde $\mathrm{http} / /$ wearesocial.com/uk/special-reports/digital-social-mobile-worldwide2015adresinden alınmıștır.

Whang, L.S.M., Lee, S., \& Chang, G. (2003). Internet over-users' psychological profiles: a behavior sampling analysis on internet addiction. CyberPsychology \& Behavior, 6(2), $143-150$.

Wentzel, K. (1998). Social relationship and motivation in middle school: the role of parents, teacher, and peers. Journal of Educational Psychology, 90(2), 202-207.

Wu, Y-T., Tsai, C.C. (2006). University students' internet attitudes and internet self-efficacy: A study at three universities in Taiwan. Cyberpsychology \& Behavior, 9(4), 441-450.

Zorbaz, O., \& Dost, M.T. (2014). Lise öğrencilerinin problemli internet kullanımının cinsiyet, sosyal kaygı ve akran ilişkileri açısından incelenmesi. Hacettepe Üniversitesi Ë̆itim

Uzun Öz Fakültesi Dergisi, 29(29-1), 298-310.

\section{Giriş}

İnternetin bireylerin yaşamına getirdiği kolaylıklar saymakla bitmez. Fakat son zamanlarda, internetin bireyler üzerindeki olumsuz etkilerinden bahsedilmektedir. İnternetin aşırı ve problemli kullanıldığında bireyin günlük yaşamındaki işlerinde, aile ilişkilerinde ve duygusal dengenin bozulmasında etken olduğu ifade edilen çalışmalar bulunmaktadır (Anderson, 2001; Davis 2001; Lin ve Tsai, 2002; Ryu, Choi, Seo ve Nam, 2004; Young ve Rogers, 1998). İnternetin aşırı kullanımı tüm bireyleri etkilediği gibi ergenlerin hayatını da olumsuz yönde etkilemektedir. Ergenlerin psikososyal gelişimleri ve davranışları üzerine zararlı etkileri olabilmektedir (Çam ve Nur, 2015). Günümüzde mobil teknolojilerin gelişmesi ile birlikte internet kullanımının artık mobil cihazlardan erişime kaydığı ve arttığı görülmektedir. Bu açıdan akıllı telefonların ve mobil internetin yaygınlaşmasının, internetin gereğinden fazla kullanılmasına yol açarak, bireylerinözellik de genç bireylerin-bağımlılıklarını arttırıcı rol oynayacağı düşünülmektedir. Bu bağlamda ortaöğretimde öğrenim gören bireylerin internet bağımlılık düzeylerinin artması, akademik başarıyı, ders motivasyonu olumsuz yönde etkilemektedir. Bu yüzden bu çalışmada, 
lise öğrencilerinin internet bağımlılık düzeylerinin belirlenmesi ve bu düzeyin akıllı telefon ve mobil internet sahipliği gibi değişkenlere göre incelenmesi amaçlanmaktadır. Özellikle genç bireylerin, interneti aşırı ve problemli kullanması sonucu ortaya çıkabilecek problemlerden biri olan internet bağımlılığının bilimsel olarak ortaya konmasının; mobil teknolojilerin gelişmesi ile artacağı öngörülen problemin önlenmesi, gerekli tedbirlerin alınması, bu problemlere karşı gençlerin korunması ve gençlerin, ebeveynlerin, ve eğiticilerin bilinçlendirilmesi açısından önemli olduğu düşünülmektedir.

\section{Yöntem}

Lise öğrencilerinin internet bağımlılık düzeyinin çeşitli değişkenler bakımından incelediği çalışmada tarama modeli kullanılmıştır.

\section{Çalışma Grubu}

Çalışma grubunu, Edirne Merkez ve İzmir'in Selçuk ilçesindeki farklı sosyo-ekonomik bölgelerde bulunan liselerden kolay erişilebilir şekilde rastgele ulaşılmış 501 öğrenci oluşturmaktadır.

\section{Veri Toplama Araçları}

Çalışmada, internet bağımlılık düzeyini belirlemek amacıyla Ayas, Çakır ve Horzum'un (2011) geliştirdiği "Ergenler için Bilgisayar Bağımlılığı Ölçeğinin" internet bağımlılığı alt ölçeği kullanılmıştır. İnternet bağımlılığı alt ölçeğinde 28 madde bulunmaktadır. Maddelerin internet bağımlılığı faktöründeki yük değerleri .512 ile .795 arasında değişmektedir. Çalışmada ölçeğin güvenilirliği için Cronbach Alfa iç tutarlılık katsayısı .94 olarak hesaplanmıştır

\section{Verilerin Toplanmast ve Analizi}

Veriler araştırmacılar tarafından ders saatleri içerisinde toplanmıştır. Öğrencilere öncelikle araştırma konusu ve veri toplama aracı hakkında bilgi verilmiş, ardından araştırmaya katılımın gönüllülük esasına dayalı olduğu hatırlatılarak her bir öğrencinin ölçeği yanıtlaması sağlanmıștır. Ölçek yaklaşık 10-15 dakikalık sürede yanıtlanmıştır. Verilerin analizinde betimsel istatistikler, Mann Whitney U ve Kruskal Wallis H testlerinden yararlanılmıştır.

\section{Bulgular ve Tartışma}

Internet Bağımlılık düzeyi açısından çalışma sonucunda ergenlerin internet bağımlılı̆̆ ölçeğinden aldığı bağımlılık puanını birçok faktörün etkilediği, fakat bununla birlikte araştırmaya alınan katılımcıların bağımlılık puanlarının düşük oldu tespit edilmiştir. Ölçekten alınan puan sınıflaması sonucu ergenlerin \%3'nün internet bağımlılı̆̆ 1 gösterdiğì, \%26,3'nün risk altında olduğu ve \%70,7'sinin ise normal internet kullanıcısı olduğu tespit edilmiştir.Ayrıca çalışmanın diğer bulgularına göre, cinsiyet, baba eğitim düzeyi, ailenin ekonomik düzeyi, akıll telefon kullanma süresi, mobil internet kullanma süresi değişkenlerine göreinternet bağımlılığı açısından anlamlı bir farkl1lık bulunamazken; sınıf düzeyi, anne eğitim düzeyi, akıllı telefona sahiplik durumu, mobil internete sahiplik duruтu değişkenlerine göre anlamlı düzeyde farklılık tespit edilmiştir.

Problemli internet kullanımı ergenlerin gelişimini, sosyal yaşamını ve akademik başarısını olumsuz yönde etkileyecek etkenler yaratabilmektedir. Bu açıdan problemli internet kullanımının iyi irdelenmesi ve buna etken olan durumların ortaya çıkarılması gerekmektedir. Ayrıca, günümüzde, yetişkinlerde olduğu gibi ergenler arasında da internetin kullanım süresi, kullanım biçimi, kullanım ortamı ve kullanım çeşitliliği artmaktadır. Bu açıdan ailelere birden çok iş düşmektedir. Öncelikle, ailelere internetin problemsiz ve olumlu kullanımları hakkında bilgi verilmeli ve ailenin, ergenlerin özellikle akıllı telefonları ile internet kullanımının denetimini sağlamaları gerekmektedir. Bu bağlamda, ailelerin, internet bağımlılığına karşı alınacak önlemlerin belirlenmesi ve işe koşulması için kullanılacak yöntemlerde de bir paydaş olarak yer alması gerekmektedir. Akıllı telefonların ve mobil internet kullanımının gençler arasında hızla yaygınlaşmasına rağmen; derslerde ve okul içi akıllı telefon kullanımının engellenmesi ya da 
sınırlanması ile öğrencilerin internet bağımlılıklarının önüne geçilebileceği ve öğrencinin derse motivasyonunu arttırarak akademik başarısı açısından olumlu etki yapacağı düşünülmektedir. Bununla birlikte, uzun vadede, okullarda internet bağımlılığına ilişkin farkındalığın arttırılması amacıyla ergenlere yönelik bilinçli internet kullanımı konularında eğitim çalışmalarının yapılması önemli görülmektedir. 